\title{
Franz Keller-Leuzinger's Exploration of the Amazon and Madeira Rivers During the Brazilian Empire: Press and Nation
}

\author{
Moema de Rezende Vergara \\ Museum of Astronomy and Related Sciences (MAST), Brazilian Ministry of Science, Technology and Innovation (MCTI), Rio de Janeiro, \\ Brazil
}

Email address:

moema@mast.br (M. R. Vergara)

\section{To cite this article:}

Moema de Rezende Vergara. Franz Keller-Leuzinger's Exploration of the Amazon and Madeira Rivers During the Brazilian Empire: Press and Nation. History Research. Vol. 3, No. 5, 2015, pp. 54-64. doi: 10.11648/j.history.20150305.11

\begin{abstract}
The relationship between travelers and the Amazon River is a subject that, for a long time, has been enticing researchers of different disciplines and from many parts of the world. Such as the river, the subject also seems endless. This paper seeks to contribute a small fragment to the larger discussion by narrating the journey of the German draftsman, cartographer, engineer and painter Franz Keller-Leuzinger through the repercussion of his writings in the Brazilian and international press of the time. Although his work has already been used as reference for researches on railroad history and photography, there are few studies dedicated exclusively to this explorer, who remains almost unknown. We seek to highlight this traveler in an attempt to understand issues related to the perception of the Amazon region by the end of the Brazilian Empire, and the contemporary projects to integrate that region to the rest of the country, within the process of building a sense of nationality based on the territory's grandeur.
\end{abstract}

Keywords: Franz Keller-Leuzinger, Travelers, Amazon

\section{Introduction}

When researching nineteenth-century publications on science, I found a note on Franz Keller-Leuzinger exploration of the rivers Amazon and Madeira. In such publications, especially from the $1870 \mathrm{~s}$ and until the Republic's first years, scientists and intellectuals were together in demanding the State to foster knowledge about the national territory. ${ }^{1}$ These intellectuals used a strongly nationalistic rhetoric, based on the grandeur of the territory and its real and imagined riches, in order to build a sentiment of "Brazilianess." The research increased my interest in Keller-Leuzinger and his trip to the Amazon as an exciting opportunity to study one of the most stimulating moments in the history of the conquest of Brazilian Western borders. Furthermore, the trip itself, which generated richly illustrated national and international publications, is an excellent opportunity to study representations of the Amazon during the Empire. Thus, with Keller-Leuzinger as guide, I investigated the context motivating his trip, and the

1 About this specific issue, see Vergara, "The Popularization of Science..." scientific knowledge it required.

It is known that the explorer was born in Mannheim, Germany, in 1835. He was a draftsman, a cartographer, an engineer, and a painter, and his artistic education took place at Düsseldorf. He arrived in Brazil in 1857 with his father Joseph, and his brother Ferdinand Keller, and took residence in the state of Paraná. There, with his father, he explored the Tibagi and Paranapanema rivers. In 1865, he joined the expedition to the Avaí River, producing numerous watercolors of the region (Vasquez, 2000, p.77). In 1867, he married the daughter of the bookseller and printer George Leuzinger, Sabine Christine, and adopted her family name. In the same year, he and his father were commissioned by the Imperial Government to study the possibility of improving navigation, and of building a railway along the Madeira River, in the Amazon Valley (Ferreira, O.,1994, p.192). It was precisely this mission that made him famous, through his writings and drawings. Keller-Leuzinger himself wrote that the repercussion of his Amazon-Madeira report ${ }^{2}$ was such

2 The original report was written in Portuguese but its translation into Spanish was found at the beginning of this research, whereas the official Brazilian 
that the renowned explorer Georg August Schweinfurth (1836-1925) invited him to draw the topographical map of the High Nile.

After the Madeira River's exploration, Keller-Leuzinger established himself in Rio de Janeiro, and worked in the photography studio of his father-in-law (Ferrez, 1985, p.60), the Casa Leuzinger. The company closed the studio in 1871 to focus on typography (Senna, 2006, p.102). Two years later, Keller-Leuzinger went back to Europe for health treatment, and settled in the German city of Karlsruhe. According to Frank Kohl, he contracted malaria in the Amazon, which was the reason why he could not accept the invitation of American Colonel George Earl Church (1835-1910) to participate in the construction of the Madeira-Mamoré railroad, which used data gathered by the Kellers in that region. ${ }^{3}$

In 1876, when Pedro II visited Germany, Keller-Leuzinger wrote him a letter to expose the plans that lured him back to Brazil. Those were very ambitious projects: he wished to have the monopoly for salt exploration in Paraná, as well as intermediating sales of German gunpowder to the Empire, and intended to go back to Brazil as an engineer, since in Germany he was living only from his artistic works:

Going back again to the beautiful beaches of Santa Cruz Land in such terms, i.e., personally accompanying to Rio de Janeiro a shipment of gunpowder, and, if necessary, of weapons, perhaps Your Imperial Majesty would deign to charge me again with technical works as formerly.

Besides the works of river exploration, road and railroad alignment, and drawing of geographical maps, allow me to mention the elaboration of projects for potable water supply in the capital, which become most urgent everyday. (KellerLeuzinger, 1876)

The letter reveals that he had as much business as scientific ambitions, but he clearly saw himself as a science man, and wanted his name along those of other scientists, such as the American geologist Charles F. Hartt (1840-1878). Keller-Leuzinger also used to state that he was encouraged by the German anthropologist Rudolf Virchow (1821-1902) to continue his scientific work. With that goal, he planned to study "everything curious and interesting that the vast empire still holds for the scientific world." Apparently, such projects never came true. He visited Brazil in the 1880s and went back to Germany, where he died in Munich in 1890.

\section{The Journey}

One of the challenges of the Empire of Brazil was the effective knowledge about the territory inherited from Portugal. Various means were used to conquer the "body of the nation," such as drawing the borders, listing the first inhabitants, and classifying its natural and economic potential, all of which contributed to conform the spirit of a Brazilian nationality. This process reinforced a mythology about Brazil,

document was only recently located. Thus, the report's quotes come from the Spanish translation.

3 See Kohl. as the "land of abundance" within a "natural border" designed by the Plata and Amazon basins. This aspiration had been vital to strengthen the State and the institutions dedicated to the territory's scientific inventory, in colonial times as well as under the Empire. ${ }^{4}$

This mindset is evidently present in cartography, which illustrates all contradictions of a country that inherited a territory closer to a concept than to a known and defined physical space. In other words, the coast and the Northern and Southern extremities were known, but the so-called "Western fringe" - precisely the region explored by KellerLeuzinger - remained unknown (Davidson,1970, p. XII).

He was not, though, the first to explore the Madeira. This river was conquered in colonial times by the bandeirantes and sertanistas* seeking to push the Tordesillas Treaty line. It was used to take away precious metals from Mato Grosso, as well as to integrate that region to the rest of the country, in spite of navigation difficulties. The Madeira River remained an important waterway even after the decline of the gold production in the eighteenth century. Cintra rightly points out that rivers can be seen as a geopolitical device within LusoBrazilian diplomacy.

Even though, as Davidson argues (1970, pp. 2-3), occupying the land was not enough to hold lands belonging to the Spanish Crown: Portuguese ambassadors would have to legitimate the conquest. Portuguese sovereignty in the Amazon region resulted from the action of local agents in America and diplomats in Europe, who made the uti possidetis case. Thus, the Madeira River becomes undeniably Portuguese - and later Brazilian - with the Madrid Treaty of 1750 (Peixoto, 2005, p.81). There was no doubt in the mid1800 s that the Madeira River was Brazilian, but it still needed to be better explored.

The context of Franz Keller-Leuzinger expedition included the opening of the Amazon River to other nations on September $7^{\text {th }}, 1866$, through the Imperial Decree n. 3749. In mid-nineteenth century, the Empire suffered international pressure, mainly from the United States, to allow other nations to navigate the Amazon. Intense debate followed the "Memphis Memorial," published in 1853 by the US Navy Lieutenant Matthew Fontaine Maury. He urged his government to act, using force if necessary, in order to obtain the desired freedom for all nations to navigate the Amazon River and its tributaries. Maury's propaganda caused outraged protests in the Brazilian press, but also fed the idea that opening the Amazon would project a positive international image of the country, a position held mainly by Tavares Bastos ${ }^{5}$ (see Martin).

\footnotetext{
4 See Kantor and Magnoli.

* Translator's Note: bandeirantes were the trailblazers in colonial times, in search of precious stones and metals, pioneering not the occupation but the exploration of the territory; sertanistas (from sertão, the outback), were expert guides in the backlands.

5 The lawyer, journalist, politician, and activist Aureliano Cândido Tavares Bastos (1839-1875) was a public advocate of federalism, as argued in his most important book, A província (The Province). He held only one parliamentary mandate, and then used mostly the press to spread his ideas, including campaigns for electoral
} 
Keller-Leuzinger supported such opinions by celebrating that "in the year 1867 the Government of Brazil finally abandoned the old narrow-minded system of colonial exclusiveness" (Keller-Leuginger, 1875, p.33). Just after 1867, the Ayacucho Treaty was signed with Bolivia and defined the borders between the two countries. Thus, according to an October $10^{\text {th }}$ ordinance, Franz KellerLeuzinger and his father were

(...) commissioned by the imperial government to explore the Madeira River in its cascading portion, from Santo Antônio Falls up to the confluence with the Mamoré River, and to elaborate appropriate projects to improve this important communication route with the province of Mato Grosso and the Republic of Bolivia (Keller, 1869, p. 2).

Moreover, one can interpret such journey as an effort of the imperial State to solve the problem inherited from the colony, i.e., the exploration of the rivers Amazon and Madeira and the country's integration, taking into consideration the communication with Mato Grosso. The convergence of these events with the production of rubber, cocoa, coffee, tobacco, and quinine, all in great commercial demand, stimulated the organization of the expedition (see Church). To connect the region with the rest of the world was not only a territorial integration issue for the Brazilian empire but also a means to export valuable raw materials to the international market. Bolivia also deemed essential to have other shipping channels for its production: as going across the Andes was not feasible, the solution found then was a route through the Amazon (Hardman, 2005, p.161). ${ }^{6}$

In the 1860 s, native seringueiros* were already working along the lower Purus and the Madeira; in the next decade, when Northeastern migrants flocked to the region, Brazilians and Bolivians camped there, while the border between the two countries remained uncertain. To Valerie Fifer, one of the consequences of the 1867 treaty was the departure of the Bolivians, leaving the area free to Brazilian occupation. The Bolivian population went to the upper Madeira, respecting an oblique line going from the source of the Javari River (still unexplored at the time) to the latitude $10^{\circ} 20^{\prime}$ South, at the confluence of the Madeira and Mamoré rivers (Fifer,1970, p.117). In other words, the area was definitely Brazilian, which justified the government efforts to explore a barely known or populated region, Ultima Thule do Brasil. ${ }^{7}$

In November 1867, Franz Keller-Leuzinger left Rio de Janeiro and navigated along the coast up to Belém do Pará, then proceeded through the Amazon River to the city of Manaus. There, he organized the expedition to the valleys of

reform and for the opening of the Amazon.

6 After the failure of the Madeira-Mamore railroad-building project, in the early twentieth century, Bolivia built railroad connections with Chilean and Peruvian ports on the Pacific.

* Translator's Note: seringueiro is the worker who extracts the latex (or seringa) from the rubber tree (seringueira).

7 Brazil's ultima Thule. The Latin idiom designated, among Romans, a region in the far North of Europe, not clearly identified as yet. In medieval geographies, it came to denote any distant place located beyond the borders of the known world. See Tocantins. the Madeira and Mamoré Rivers. In seven canoes, the cargo consisted of provisions for four months, tools for fixing canoes, ropes, tents, weapons, medicines, and gifts for the valleys" "savage and half-savage tribes" (KELLER-LEUZINGER, 1875, p.42). The crew included himself and his father; the Brazilian engineer Joaquim Manuel da Silva, "our assistant technician"; an Italian merchant coming from Bolivia; a German referred to only as P.v.S. (and described as a young adventurer, experienced in such expeditions in other parts of the world, including one with Keller-Leuzinger himself), and 80 "Mojos and Canichana Indians, (...) sons of the plains of the Mamoré and Itonama" (KELLER-LEUZINGER, 1875, p.42). The natives, including pilots for the canoes, were expert rowers, and were incorporated to the expedition with the help of the Italian merchant, who was introduced to KellerLeuzinger by the Bolivian vice-consul in Manaus. The English translation of the original German book mentions five White men by name or function but the Spanish translation of the report the Kellers prepared for the Brazilian government numbers eight of them and only 70 natives, instead of 80 (KELLER, 1870, p.3). In any case, the exploring adventure along the rivers expanded the understanding of the term "border," which could mean an area with fluid limits, including its own social and cultural practices, not to be confused with territorial limits.

The main goal of the expedition was to estimate the costs for the construction of a railroad along those rivers, including some channeling works, as well as twenty inclined planes between the Santo Antônio and the Guajará Falls. In their report, the Kellers concluded that the transportation system based on canoes and rowers completely precluded the possibility of developing trade in the region. The authors pointed out that, once the engineering works were completed, the indigenous population of the Bolivian province of Beni, "who nowadays is physically and morally destroyed by an unfruitful navigation, will be able to go back to their usual occupation on agriculture and industry" Keller, 1870, p.72). The Kellers also recommended the construction of inclined planes in order to increase the cargo capacity from eight to thirty tons.

The expedition arrived to the Madeira River on July 1868, and found it four meters below its usual depth - in convex riverbanks, sandbars were increasing (Keller, 1870, p.5). Keller-Leuzinger also recorded the complaint of the Madeira seringueiros against the Bolivians, who apparently did not bring enough provisions, and often stole from what Brazilians cultivated by the river (Keller, 1870, p.5). It is a report that brings some perspective to the idea of an abundant Amazon region, still very popular: travelers who did not bring with them the necessary provisions could starve to death, as some areas of the forest do not provide fruits or fishes.

The upper Madeira geography has a number of falls around the agitated confluence with the Mamoré. When the expedition arrived there, they had to unload and carry the canoes with the help of ropes. This laborious task was repeated many times along the way. Between the Morrinhos and the Caldeirão do Inferno Falls, the expedition met some 
canoes of the Caripuna natives, known to Keller-Leuzinger as hostile to White men. But there was no conflict, and he even offered them gifts in exchange for manioc roots and corn
(Keller-Leuzinger, 1875, pp. 57-58).

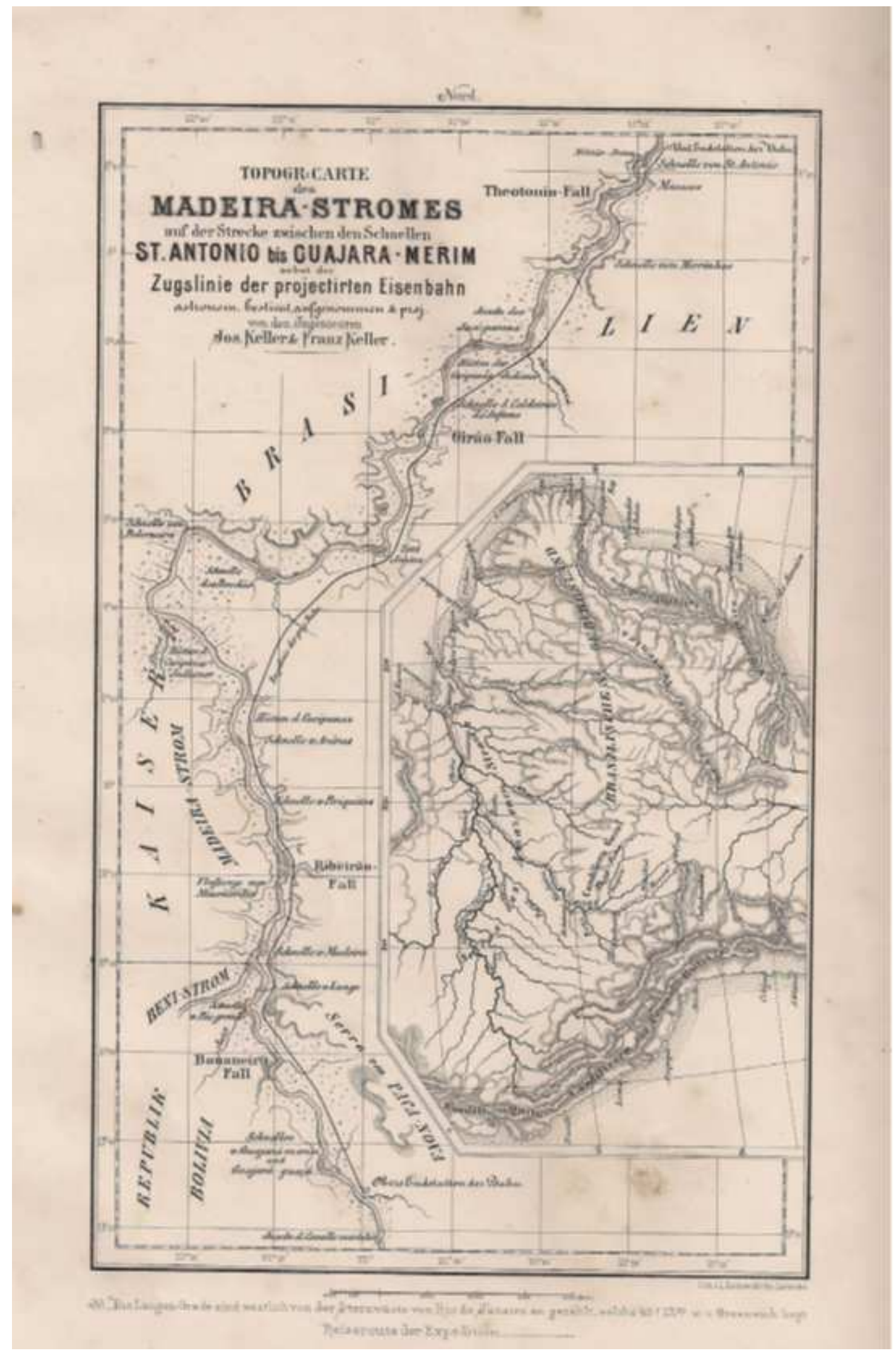

Source: Library of the Brazilian Geographical and Historical Institute (IHGB). 
Figure 1. Franz Keller-Leuzinger's map of the journey's itinerary, published in the book Vom Amazonas und Madeira.

The Caldeirão do Inferno Falls had the worst reputation: its strong currents had already killed many a navigator, throwing boats against rocks and swallowing them in whirlpools. Afterwards, the expedition arrived at the lower side of the Ribeirão Falls, formed by five cascades that Keller-Leuzinger deemed the most remarkable ones, reaching a height of 13 meters. Such descriptions, besides adding drama to the report, also included a logic behind the recommendation to build inclined planes, thus controlling the rapids and enabling navigation in those rivers, as expressed in the report sent to the Ministry of Agriculture.

When they reached the Beni River, in the surroundings of the Guajará-Guassú Falls, Keller-Leuzinger met a large Bolivian trading group, carrying tallow and leather, and asked them to take his reports and letters to Pará and Rio de Janeiro. Apparently, his papers did not reach the destination, as in his final report he wrote that the lack of news stirred rumors about the failure of the expedition and the disappearance of its members. The passage shows how difficult it was to communicate in an area away from urban centers, and devoid of a telegraph network.

The expedition's fieldwork consisted in making hydrographic and hypsometric surveys, determining geographic coordinates from astronomic observations in a region scarcely mapped. To establish geographic coordinates, it was necessary to determine longitudes. ${ }^{8}$ Keller-Leuzinger wrote that his "ship's chronometers (by Poole, of London)," an essential tool to move the hour in the longitude calculation, ${ }^{9}$ had already malfunctioned in Manaus. He also noted that "former explorations ha[d] convinced us that these delicate instruments suffer" from the unstable conditions of a canoe journey, becoming inefficient to determine longitudes. Thus, to solve the problem, he used lunar differences to find coordinates. He regretted that such method did not allow for the same precision in all measurements, as observation depended on weather conditions (Keller-Leuzinger, 1875, p.204).

In the 1869 report, he described such measurements: latitudes were determined according to the height of the sun and the stars, almost always calculated at the expedition's camping locations. Nocturnal observations were favored by the cloudless sky of the dry season. The explorer used a Casella reflection circle and two sextants with artificial horizons. He also used a Rychon micrometer and a prismatic compass to establish the course of the rivers. However, he did not arrange triangulations for lack of personnel and for the difficulties of working in dense forest. According to

8 Longitude was calculated by the time difference in the passage of a star through the meridian in two different places, i.e., one observes the star's transit in one place, and then in another place, using a celestial catalogue to determine longitude in any point of the globe.

9 Each hour represents $15^{\circ}$. Rio de Janeiro, for instance, is three hours behind Greenwich, i.e., it has a longitude of $45^{\circ}$ West. See Vergara, "Ciências, fronteiras..." p. 356.
Neville Craig, the German engineer did a valuable job in compiling maps of the Madeira River:

Keller gathered a great amount of information about the region, and mostly confirmed Lieutenant Gibbon's ideas. * He compiled maps of the river, in large scale, and proceeded to careful surveys, but as he could not count on his chronometers, ruined by excessive use, and was forced to depend on lunar observations for longitude calculation, it was later verified that there were considerable differences in his maps, in the East-West direction.** (Craig p. 31)

The topography's altitude was measured with barometers and hypsometers. Along with scientific instruments, it is almost certain that he took with him the Anuário do Imperial Observatório (imperial observatory yearbook) for geodesic calculations, as the meridian used in his coordinates was Rio de Janeiro. In a note in his 1874 book, when presenting Rio's average temperatures, he even refers to the observatory, where weather measurements were taken: "Two and a half or three and a half degrees more must be counted for the city as the Observatory is situated on the Morro do Castelo [the Castelo Hill], several hundred feet above it, where it is swept by the cool sea-breeze" (Keller-Leuzinger, 1875, p. 2).

The westernmost part reached by the expedition was the city of Exaltación, in Bolivia, where he replenished his provisions, and hired more rowers for the journey back. He also visited the ancient Jesuit mission, founded in early eighteenth-century by the banks of the Mamoré River, on the Cayubaba tribe land (Keller, 1870, p.19; Keller-Leuzinger, 1875,p.2). For the German engineer, catechesis was the only hope to integrate natives, preventing a destiny of greater exploitation, since "whenever they have come into contact with the White race, their doom has been sealed. Like their more energetic Northern brethren, they are visited with physical and moral destruction; the rate of which can be retarded only by founding aldeamentos ${ }^{*}$ after the plan of the former Missions, but with the condition that less care be paid to the religious, and more to the agricultural and industrial element" (Keller-Leuzinger, 1875, p.155).

In November 1868, the expedition ended in Manaus, where they had to return weapons and other utensils, and bid farewell to the province's president (Keller, 1870, p.26). Keller-Leuzinger did not specify what utensils were those. The expedition was indeed armed, but there are no records of conflicts in the report. On January $4^{\text {th }}, 1869$, "a little less sunburnt [sic], and unweakened [sic] by intermittent fevers," the explorer was back in Rio de Janeiro, which he had left

* Translator's Note: In 1851, the United States government commissioned Lieutenant Lardner Gibbon to study the viability of a rail link between the navigable Amazon River and Bolivian production centers, particularly of rubber. Gibbon's study concluded that a railroad along the Madeira River rapids would allow efficient transport of Bolivian goods to US markets.

** Translator's Note: Free back-translation from the Portuguese translation.

* Translator's Note: Sic. Spanish and Portuguese for a village organized for natives by religious or secular authorities. The author is most probably referring to Jesuit missions. 
“fourteen months before" (Keller-Leuzinger, 1875, p.84).

The final report, an often quoted document in researches about the Madeira-Mamoré railroad, was published in 1869 and signed by José and Francisco Keller*, under the title Relatório da Exploração do Rio Madeira na parte compreendida entre a cachoeira de Santo Antônio e a barra do Mamoré (report on the exploration of the Madeira River between Santo Antônio Falls and the confluence with the Mamoré River). In twentieth-century Brazilian historiography, the Kellers trip to the Amazon was not always well appreciated. In his book Introdução à História Ferroviária do Brasil, Ademar Benévolo placed the Kellers within "an invasion of foreign technicians in the so-called Second Empire" (Benévolo, 1953, p.587). The author points out that the imperial government legitimated and fostered the presence of foreigners through a decree of the Ministry of Agriculture in 1862, which required the nomination of engineers - mostly foreigners instead of Brazilian technicians, who, according to Benévolo, could have done the job.

For another author, Manoel Rodrigues Ferreira, the Kellers were chosen because of the "because of the [inferiority] complex Brazilian officials felt regarding foreign technicians" (Ferreira, M. 2005, p. 67). Ferreira also evaluated their work as not quite positive: according to him, those engineers were around the cascades for only four months, which would not be enough to produce a detailed project of the solutions presented in their final report. The costs were mere estimates, not based in facts. For the railroad, they estimated the cost of 8.500:000\$000 and, for the inclined planes, 21.000:000\$000**. However, for this author, the merit of their efforts was in the conclusions: the railroad route should follow the rapids portion of the Madeira and should necessarily cross the delta of the Beni River, in order to collect trade cargo coming from it.

As mentioned, such data was transferred to George Earl Church, who was hired by the Brazilian government to build the railroad, and who founded the Madeira \& Mamoré Railway Company. Church was not only authorized to build it, but also to explore the railroad service for fifty years. On January $24^{\text {th }}, 1869$, the Diário Oficial do Império (official daily of the empire) published the following:

After the Brazilian government opened the Amazon and its main tributaries to friendly flags, a great economic revolution started to develop, slowly in the beginning, but promising to take immeasurable proportions in the future. The first notable consequence of the magnanimous act of the Brazilian government was the contract just celebrated between the Bolivian government and the American engineer George E. Church to navigate the Mamoré and other tributaries of the Madeira belonging to the Republic, and also, in agreement with the Brazilian government, to execute the great works of the railway that must avoid the rapids of that river.

Developments of the Keller-Leuzinger expedition were not

\footnotetext{
* Translator's Note: Portuguese version of their names, Joseph and Franz.

** T.'s N.: Eight and a half million contos de réis, and twenty-one million contos de réis.
}

productive. In 1872, having the Bolivian government as guarantor, Church obtained a loan of 1.7 million sterling pounds from British bankers. Until 1879, he hired two American and two British contractors, all of which failed in building the railroad. In 1881, the Brazilian government cancelled the concession given to the American colonel, according to Ernesto Mattoso Maia Forte, a member of the Church commission, who published in 1883 the book Do Rio de Janeiro ao Amazonas e Alto Madeira (from Rio de Janeiro to the Amazon and the Upper Madeira). The railroad construction would only start in early twentieth century, and it would never be efficiently used (see Hardman).

\section{Vom Amazonas und Madeira}

In 1874, Keller-Leuzinger published in German his book Vom Amazonas und Madeira, including 68 beautiful engravings executed at the Xylographische Anstalt von A. Closs, of Stuttgart. The engravings were by his brother Ferdinand, based on Franz's sketches (Ferreira, O. 1994, p.192), and the book had seven chapters, an appendix and a map. Largely based on the 1869 report, the journey's narrative ends in the second chapter. The author reserved the rest of the book to describe life in the region, including hunting and fishing, culinary, vegetation, the native tribes of the Madeira Valley, and the Jesuit catechesis.

His main goal, stated in the introduction, was to attempt an answer to the question of why Brazil, a country rich in nature's gifts, "has as yet failed to reach a higher degree of development" (Keller-Leuzinger, 1875, p.20). He treated nature as a variable in the equation of civilization and progress, as done in Chapter V, "The Vegetation of the Virgin Forest of the Amazon and the Madeira." Here is a description of the Amazon forest, where "Nature, undisturbed by man, has created her own prodigies, and where no narrow pots separate her children from the maternal soil, and where no dim roof of glass intervenes between them and the blue ether!" (Keller-Leuzinger, 1875, p.113).

However, his narrative was far from an idyllic journey through the Amazon. Among the forest riches he named the rubber tree, which supplies the latex used in manufacturing numerous products, from galoshes to the rubber protection of telegraph wires, and points out that its potential was not yet fulfilled. Worried about the exploitation and probable exhaustion of this resource - all rubber exported by Pará came from the forest - , he regretted the absence of efforts towards an organized and concentrated cultivation of the tree:

The planting of the Siphonia elastica would be a more profitable investment, as it yields the precious milk in the comparatively short space of twenty or twenty-five years; but, under the combined influence of the indolence of the mestizoes [sic] and shortsightedness of the Government, measures to that end will be adopted and carried into effect only when the rubber exportation shall have diminished with the destruction of the trees, and when European and North American manufacturers shall have found out a more or less appropriate substitute for the too costly resin. (Keller- 
Leuzinger, 1875, p.117)

Later on, importers indeed found a surrogate for the Amazonian rubber.

The German engineer had a pessimistic vision of the Amazonian natives. Under a clear influence of mesological ${ }^{*}$ determinism, he deemed that only the "red skins" of Mexico, Central America and Peru went from the condition of nomads to that of cattle breeders, and farmers, thus reaching the highest degree of civilization. The rest of America remained engulfed by the forest, which hindered cattle breeding, reduced agriculture to a minimum and dispersed the tribes (KellerLeuzinger, 1875, p.133). However, he did not see a solution in the elimination of natives, as was happening then in the United States, but in miscegenation. To Keller-Leuzinger, the natives were the human group best adapted to the tropics, and a process of "amalgamation" should produce a new generation, a stable and weather-adapted race. If it were not gifted with the work capacity of Europeans, wrote the German explorer, at least it would be able to live pacifically with Whites. He had heard numerous reports of conflict, although he did not suffer any native attacks in his journey.

In Pará, colonels* bought the forest products from collectors at very low cost and sold them for the triple of the price. To make things worse, as Keller-Leuzinger noted, rubber was not paid in money, but in provisions, which created a system of indenture, keeping the population of natives and mestizos under permanent tutelage. Thus, the German traveler anticipated Euclides da Cunha's $A$ margem da história (on the margins of history) denunciation of work conditions in seringais ${ }^{* *}$.

\section{The Circulation of Keller-Leuzinger's Book}

In 1874, when Vom Amazonas und Madeira was published, the French magazine Le Tour du Monde reproduced 23 of the 68 original engravings along with an article by KellerLeuzinger, translated from German by J. Gourdault. According to Michel Riaudel, the article inspired Jules Verne's novel La Jangada (1881), especially in the references to some mythical entities of the Amazon. Riaudel believes that not only the text, but also the drawings in Keller-Leuzinger's work inspired some passages of Verne's book - he points out specifically the alligator attack endured by the characters in Chapter XVII (RIAUDEL, 2007, p. 67). Keller-Leuzinger's work was not only present in fiction and news magazines but also in other scientific books, such as the one published by the French geographer Élisée Reclus, Nouvelle Géographie Universelle, la terre et les hommes, published in 1894. Reclus quotes Keller-Leuzinger in the

\footnotetext{
* Translator's Note: Mesology is a nineteenth-century term for ecology or environmentalism.

* T.'s N.: In 1831, when the first National Guard was created, the rank of colonel was liberally distributed to latifundia and plantation owners across the country. This Guard was dismantled in 1922.

** T.'s N.: Plural of seringal, a grove of rubber trees.
}

chapter about the Amazonian region, particularly in what concerns ethnography and descriptions of the local geography.

Chapman \& Hall published the first English version of Vom Amazonas... also in 1874. In the next year, James Sprent Virtue published a second edition also in England, under the title Amazon and Madeira Rivers: Sketches and Descriptions from the Note-Book of an Explorer, which is still on sale and was consulted for this paper. There is no mention of a translator. The second English edition had weights and measures converted to the British system, and Royal Geographic Society naturalist Henry Walter Bates, who also visited the Amazon in 1847, reviewed the text. In the United States, J. B. Lippincott published the book in Philadelphia in 1875.

Up to this moment, Vom Amazonas und Madeira has not been translated into Portuguese. The most extensive reference to it in this language was a series of six articles and 22 drawings published in the luxury magazine Ilustração Brasileira, of the brothers Karl and Heinrich Fleiuss, between July 1876 and May $1877 .{ }^{10}$ The series emphasizes the description of native population, and usual practices in the region:

The Amazonian industry is almost all extractive, as Brazilians themselves state. Which means that such industry depends almost exclusively on a kind of spoliation of the territory. Man's work has an insignificant role; everything comes from Nature's exuberance, offering a tribute of continuous rebirth. (KELLER-LEUZINGER, 1876,Part I, pp. 5-7)

Orlando da Costa Ferreira believed that the brothers Fleiuss simply translated the full text of the French magazine Tour du Monde (FERREIRA, O. 1994, p.192). A careful comparison of the two publications, though, reveals that only a few passages and the title (the Portuguese Viagem d'Exploração ao Amazonas e ao Madeira is indeed a literal translation of the French Voyage d'Exploration sur l'Amazone et le Madeira) are the same. Besides, the Fleuiss were German, and would not need a French version to publish excerpts of Keller-Leuzinger's book in their magazine. Moreover, different images illustrate the French and the Brazilian publications.

According to Joaquim Marçal Ferreira de Andrade, Ilustração Brasileira is an important milestone in the history of the press in Brazil, among other reasons for marking the consolidation of lithography over xylography. Two European magazines, the French L'Illustration, and the British The Illustrated London News, both richly illustrated with large format xylographs, inspired the publication. Most images published by Ilustração Brasileira were imported; few were produced in Rio de Janeiro, on imported plaques. "Even taking into consideration that the matrixes were German,"

\footnotetext{
* Translator's Note: The Fleuiss are usually referred to by the Portuguese version of their names, Carlos and Henrique.

10 Ilustração Brasileira appeared every two weeks, printed by the Imperial Artistic Institute, which was founded by the brothers Fleiuss in 1860 . Because of its luxurious layout, the magazine went bankrupt in 1878 .
} 
this author deems the publication of Keller-Leuzinger's article a landmark in the history of Brazilian illustrated magazines' layout (Andrade 2011, p.62).

Rafael Cardoso also examined the layout of the magazine, a major star in nineteenth-century Brazilian editorial production, and pointed out that a number of editors and layout men dealt with the contents, sometimes substantially altering the original. In his analysis, Cardoso underlined the inventive character of such editions, which used a great variety of technical solutions. This indicates a dynamic and autonomous process for the transmission of ideas, disavowing a common historiography misconception, according to which intellectual life in Brazil was doomed to the mere copy of what was created in other latitudes. Projects such as Keller-Leuzinger's publication in Ilustração Brasileira were the the fruit of a visual and material culture conditioned by practices of reading, selling, and collecting (CARDOSO,2009, p.73).

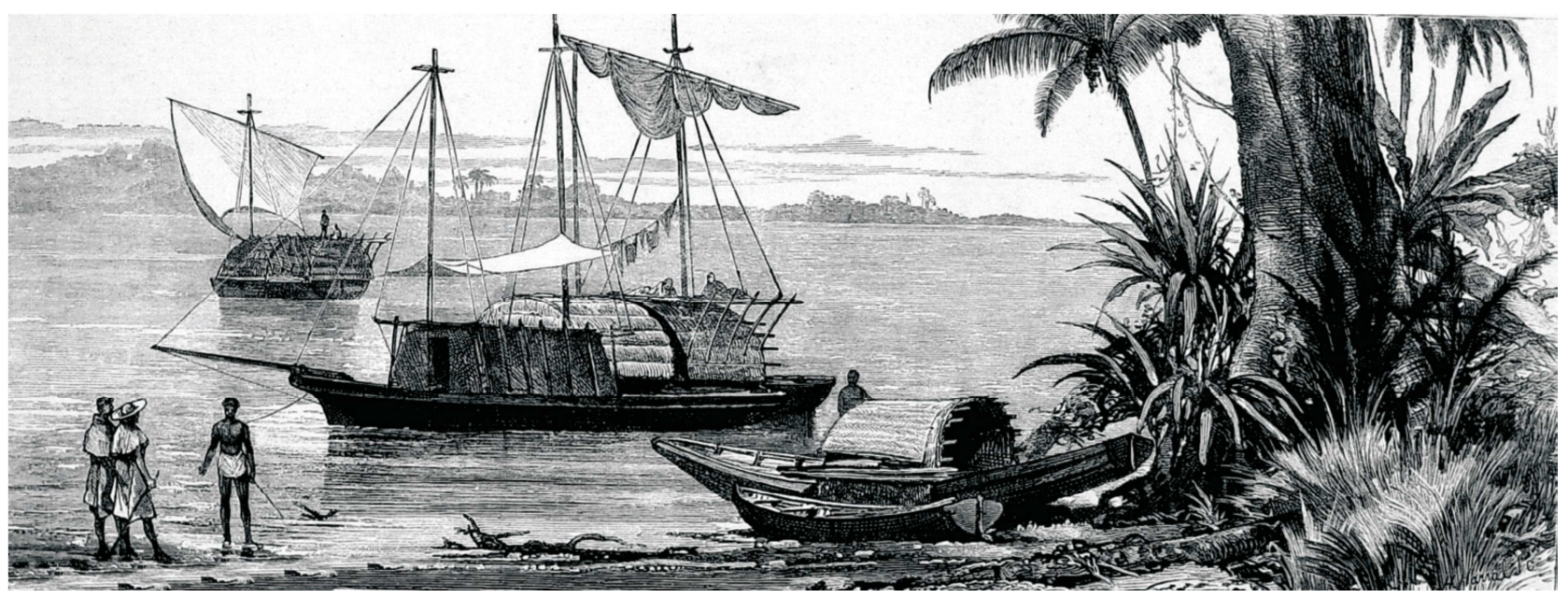

Source: National Library of Brazil.

Figure 2. "Ancient navigation in the Amazon River," Ilustração Brasileira, 1877.

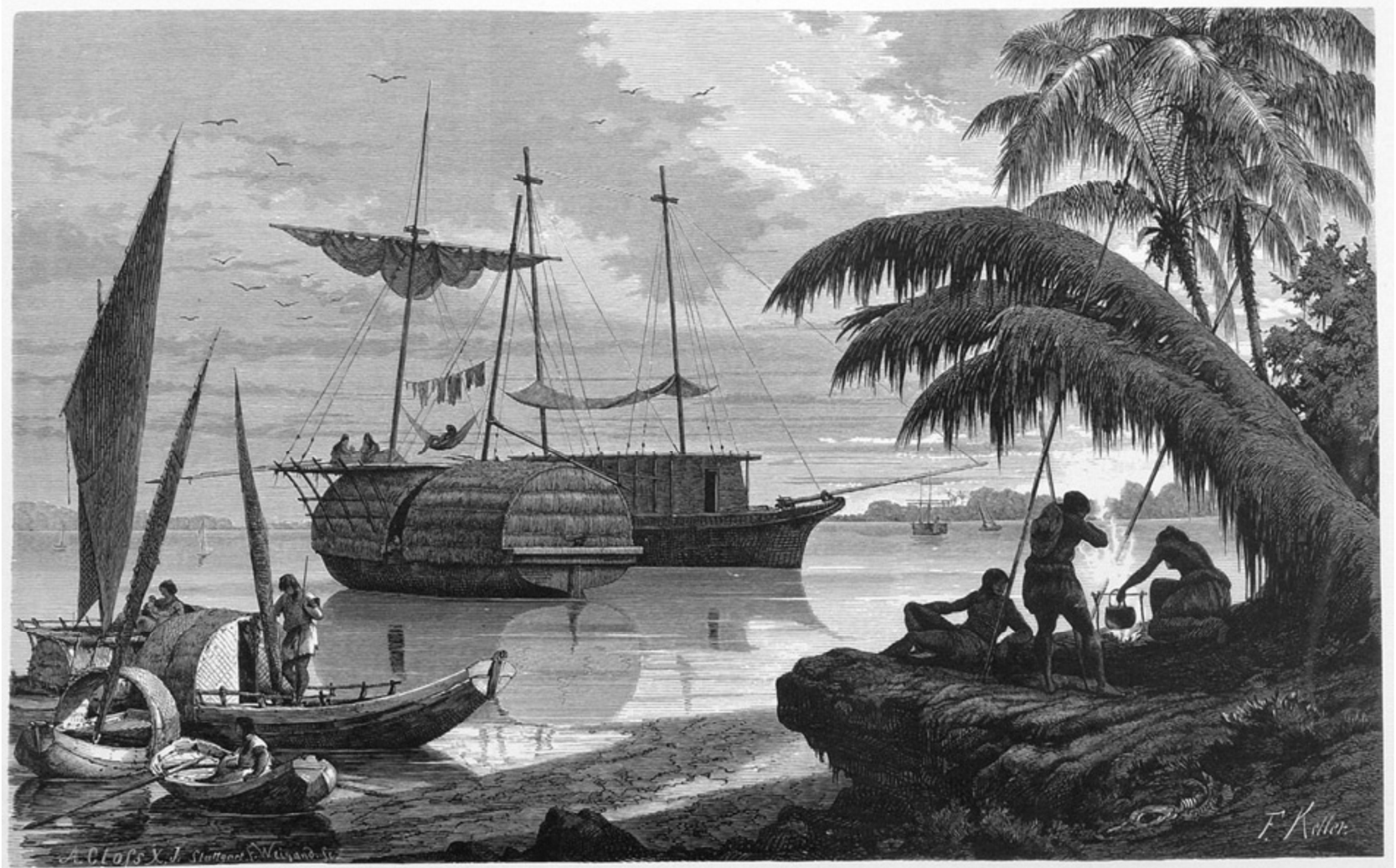

FAHRZEUGE VOM AMAZONAS UND RIO NEGRO.

(Coberta, Batelão, Igarité und Montaria.) 
Figure 3. Kinds of vessels in the Amazon River, Vom Amazonas und Madeira.

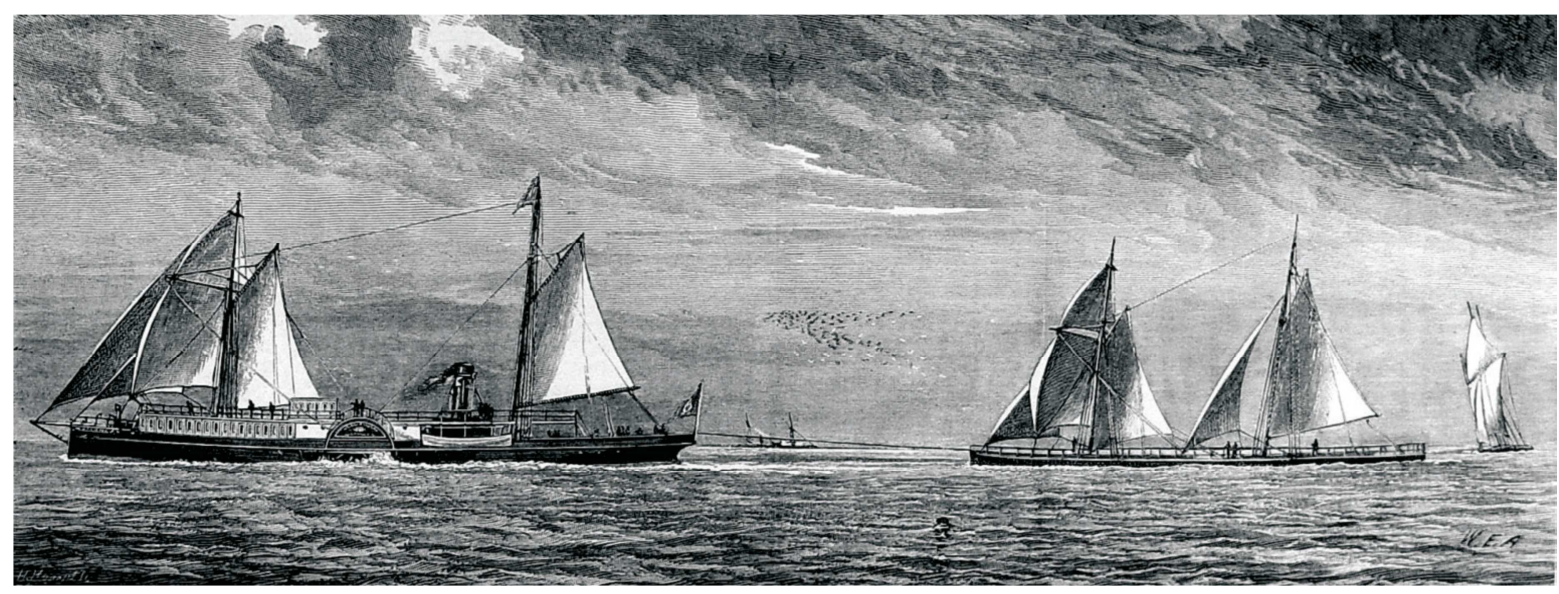

Source: National Library of Brazil.

Figure 4. “Current navigation in the Amazon River,” Ilustração Brasileira, 1877.

Indeed, in his work about Vom Amazonas und Madeira, Heinrich Fleuiss, the editor, was more innovative then the French editor at Le Tour du Monde: his balance between text and image broke the linearity of the text block and induced the reader's eyes to wander through the whole page in order to keep reading. In the last installment of the series, Fleuiss inserted two images that were not in the original book, with the captions "Navegação atual do rio Amazonas" (current navigation of the Amazonas River) and "Navegação antiga do rio Amazonas" (ancient navigation of the Amazon River). ${ }^{11}$ The latter is similar to an image in KellerLeuzinger's book, but careful examination reveals the difference. In the book, this image illustrates a variety of vessels used to navigate the Amazon, such as coberta, batelão, igarité and montaria.

These images and captions, contrasting current and ancient vessels, resulted in information that was not in KellerLeuzinger's book. The innovative image used in the Brazilian publication came from the same Stuttgart studio, but was signed W.E.A., not F. Keller, as the other drawings of the book. It probably came by mistake, and Fleiuss redesigned the page to include it.

It has to be mentioned that text and image were not always a match in the magazine's series of articles. For instance, the article where the two images abovementioned appeared described the catechesis of natives, and ended with the announcement of a continuation that never happened. Thus, the reader had an incomplete narrative of the journey. Nonetheless, Keller-Leuzinger's images continued to be used by Ilustração Brasileira: vignettes representing indigenous utensils, and used in Keller-Leuzinger's book, illustrated in 1878 advertisements of services offered by the Imperial Artistic Institute, with no credit to the author.

The first image published in the newspaper $O$

11 Keller-Leuzinger, F. “Viagem d'Exploração...” Part VII, pp. 340-341.
Vulgarisador, of Emílio Zaluar, which circulated in Rio de Janeiro between 1877 and 1881, showed the encounter of Franz Keller-Leuzinger's expedition and Caripuna natives. The editor praised the German book, which should interest all who appreciate works of that nature, unfortunately still so scarce among us (KELLER-Leuzinger, 1877, p.10). In the text, the Caripunas are thus described:

They were strong creatures, well formed, and of medium height; they had long black hair; one of the men had them braided. A tapir tooth pierced the tip of their ears, and they also had a small bunch of scarlet toucan feathers piercing [the cartilage between their nostrils]. They sported no weapons in this circumstance, and the presence of one of their women in the vessel told us about the benevolence of their intentions. (Keller-Leuzinger, 1877, p. 10)

The value of his book's engravings and his connection with George Leuzinger caused Keller-Leuzinger to be often remembered by Brazilian iconographic historiography. The work of Ana Maria Belluzzo about his drawings in O Brasil dos viajantes is a good example of such interest. She did an insightful analysis of the passage from drawings to xylographs, pointing out that this process highlighted the human image, which was just latent in the original sketches: "the classical poses of the figures, and the anatomical conception allow the harmonization of inner moves and correspond to requirements of valorization of the human, in agreement with the neoclassical conception of the time" (Belluzzo, 1994, p.138). The strength of men represented in the German engineer's drawings comes from there, which makes the following passage a little contradictory:

The drawings result from a focus on a vital sense, introduced by a palpitating nature, from which the artist accepts the gigantism to indulge in sublime expression. His theme is the untamed nature, to which man is subject. KellerLeuzinger exposes the rivalry between man and nature through the combats between natives and animals, through 
the action of tapir hunters and gatherers. This conception is peculiar of the so-called European romanticism, which finds in the landscape and in the natural man one of its expressions, conceptions closer to Rousseau's optimistic genealogy (Belluzzo, 1994, p.138).

It is clear that, in this interpretation of the drawings published in Vom Amazonas und Madeira, Belluzzo did not consider the text. For an efficient iconographic analysis, it is important to be aware of the dynamics between text and image, pointing out any complementary relationship between the two records, as well as any contradiction. One who reads KellerLeuzinger's reports finds it difficult to agree with Belluzzo and the supposed influence of Rousseau's bon sauvage in the German engineer's work. Quite the contrary: in the book, he even claims being far away from joining the unsustainable lamentation of novelists about the "eminence of a mythical Red race, which would be superior to Whites in their heroic virtues and noble qualities of spirit. Such Red race exists only in their imagination" (Keller-Leuzinger, 1877, p.157).

For Keller-Leuzinger, the Amazon had a series of disadvantages. He specifically mentions the native, who was "indolent, sensuous, and sometimes treacherous, but who was close to extinction, as he would have to bow to the requirements of overpopulated Europe" (Keller-Leuzinger, 11877, p.157). For the Empire, according to him, the solution was in agriculture and industry, which would have to overcome the extractive system that has no ordered planning, and does not promote the desired development, risking the exhaustion of natural resources in a few generations.

The analysis of the circulation of Keller-Leuzinger's work demonstrates how the Amazon region and its population were represented in the national and international press. The specificity of this traveler's narrative is in the excellence of the images, which reached great circulation due to the mechanical reproducibility of the press at the time, making, in some instances, the strength of the image outshine the text.

\section{Conclusion}

The analogy that compares the Amazon Valley to a "closed book," which should be opened mainly by savants and scientists, lasted very long and still remains a general intuition that some chapters were not yet read. Although there were many visitors to the region from the sixteenth-century on - such as Pinzón, La Condamine, Agassiz, Martius, Barbosa Rodrigues, Wallace, Bates and Hartt, among others -, the impression of terra ignota remains. This could be attributed to many factors, including the resistance offered by the object of study itself to knowledge-gathering efforts. Furthermore, the term "Amazon" hides a geographic, topographic and economic diversity, i.e., as Arthur Cézar Reis defines, "the Amazon is not just one" (Reis, 2001, p.23). Thus, one cannot generalize from the report of just one traveler. For instance, the falls found by Keller-Leuzinger are not present in all tributaries of the Amazon basin, and long extensions of the rivers are highly navigable. It is important to make this point in order to disavow the idea that the
Amazonian region is homogeneous, a misconception that is far from reality.

To effectively and symbolically appropriate that area of the territory, integrating it to the rest of the country, the press doubtlessly had an important role. In his book Imagined Communities, Benedict Anderson had already pointed out the relationship between the circulation of printed materials and the collective construction of a common past for the nation. Advancements in printing techniques on the second half of the nineteenth century enlarged the circulation of newspapers and magazines, often illustrated. Travel reports were a subject of interest - when published, readers could "visit" distant and unknown places, developing a sentiment of belonging to something they never saw before.

\section{Acknowledgements}

Translated into English by LEDA BECK. Support by FAPERJ (State of Rio de Janeiro Research Foundation)

I wholeheartedly thank Robert Wegner, Joaquim Marçal Ferreira de Andrade, and Frank Stephan Kohl, colleagues that kindly discussed ideas, and pointed out bibliography that made this work possible.

\section{References}

[1] Anderson, B. (1991) Imagined Communities: Reflections on the Origin and Spread of Nationalism. Revised Edition ed. (London and New York: Verso).

[2] Andrade, J. M. F. de (2011) A trajetória de Henrique Fleiuss, da Semana Ilustrada: subsídios para uma biografia, in Knauss, P. et al. (orgs.) Revistas Ilustradas: modos de ler e ver no Segundo Reinado (Rio de Janeiro: Mauad; Faperj), pp. 53-66.

[3] Belluzzo, A. M. de M. (1994) O Brasil dos Viajantes, vol.2 (São Paulo: Metalivros).

[4] Benévolo, A.(1953) Introdução à História Ferroviária do Brasil (Recife: Edição Folhada Manhã).

[5] Cardoso, R. (org.) (2009) Impresso no Brasil (1808-19030): destaques da história gráfica no acervo da Biblioteca Nacional (Rio de Janeiro: Verso Brasil).

[6] Church, G. E. (1875) Explorations made in the Valley of the River Madeira, from 1749to 1868. (London: brochure published for the National Bolivian Navigation Company).

[7] Cintra, J. P. (2009) O Mapa das Cortes: perspectivas cartográficas, in Anais doMuseu Paulista, 17(2), pp. 63-77.

[8] Craig, N. (1947) [online]. Estrada de Ferro Madeira-Mamoré: história trágica de uma expedição. Available online at http://www.brasiliana.com.br/brasiliana/colecao/autores/140/N eville-B-Craig. (accessed 14 March 2013).

[9] Cunha, E. (2005) À Margem da História (Rio de Janeiro: Academia Brasileira de Letras).

[10] Davidson, D. M. (1970). Rivers and Empire: the Madeira Route and the Incorporation of the Brazilian Far West, 17371808. Yale University, PhD dissertation. 
[11] Diário Oficial do Império do Brasil (1869) January 24th.

[12] Ferreira, M. R. (2005) A Ferrovia do Diabo (São Paulo: Ed. Melhoramentos).

[13] Ferreira, O. da C. (1994) Imagem e Letra.( São Paulo: EdUSP).

[14] Ferrez, G. (1985) A fotografia no Brasil: 1840-1900. 2nd ed. (Rio de Janeiro: Funarte).

[15] Fifer, J. V. (1970) The Empire Builders: A History of the Bolivian Rubber Boom and the Rise of the House of Suarez, in Journal of Latin American Studies, 2, pp. 113-146.

[16] Forte, E. M. M. (1883) Do Rio de Janeiro ao Amazonas e Alto Madeira.

[17] Itinerário e Trabalhos da Comissão de Estudos da Estrada de Ferro Madeira Mamoré. De um membro da mesma comissão (Rio de Janeiro: Typ. Soares \& Niemeyer).

[18] Hardman, F. F. (2005). Trem Fantasma: a ferrovia MadeiraMamoré e a modernidade na selva (São Paulo: Companhia das Letras).

[19] Kohl, F. S. (2006) Um jovem mestre da fotografia na Casa Leuzinger, in Cadernos de Fotografia Brasileira/IMS, 3, p. $185-214$.

[20] Kantor, Í. (2007) Usos diplomáticos da ilha-Brasil Polêmicas cartográficas e historiográficas, in Varia História. 23(37), p. $70-80$.

[21] Keller, J. and Keller, F. (1869) [online] Relatório da exploração do Rio Madeira na parte compreendida entre a cachoeira de Santo Antônio e a barra do Mamoré, in BRASIL. Relatório do Ministério da Agricultura, Comércio e Obras Públicas. Available on line at http://www.crl.edu/brazil/ministerial (accessed 13 March 2013).

[22] Keller, J. and Keller, F. (1870) Exploracion del Rio Madeira en la parte comprendida entre la cachuela de SanAntonio y la embocadura del Mamoré. La Paz: Imprenta de la Union Americana, by Cèsar Sevilla.

[23] Keller-Leuzinger, F. 1876. Letter to D. Pedro II, July 29th, Manuscript section at the Brazilian National Library.

[24] Keller-Leuzinger, F. (1876) Viagem d'Exploração ao Amazonas e ao Madeira, Part I, Ilustração Brasileira, n. 1, pp. $5-7$, July 1 st.

[25] Keller-Leuzinger, F. (1877), Viagem d'Exploração ao Amazonas e ao Madeira, PartVII, in Ilustração Brasileira, n. 2, May 15th, pp. 340-341.

[26] Keller-Leuzinger, F. (1877) Encontro com os índios Caripunas, in O Vulgarisador, n.1.

[27] Keller-Leuzinger, F. (1875) The Amazon and Madeira Rivers: Sketches and Descriptions from the Note-Book of an Explorer. (Philadelphia: J. B. Lippincott).

[28] Keller-Leuzinger, F. (1874) [online]Voyage d'Exploration sur l'Amazone et le Madeira, in Le Tour du Monde. Available at http://gallica.bnf.fr/ (accessed 13 March 2013).

[29] Magnoli, D. (2003) O Estado em busca do seu território, in Terra Brasilis, 4-5, p. 27-44.

[30] Martin, P. A. (1918) [online] The Influence of the United States on the Opening of the Amazon to the World's, in The Hispanic American Historical Review, 1(2). Available at http://www.jstor.org/stable/2506100__accessed 13 November 2012)

[31] Peixoto, R. A. (2005). A máscara da medusa: A construção do espaço nacional brasileiro através das corografias e cartografia no século XIX. Unpublished $\mathrm{PhD}$ tesis, (Universidade Federal do Rio de Janeiro).

[32] Reclus, É. (1894). Nouvelle Géographie Universelle, la terre et les hommes, Vol. XIX ,Amérique du Sud. (Paris: Librairie Hachette et Cie).

[33] Reis, A. C. F. (2001) A Amazônia e a integridade do Brasil (Brasília: Senado Federal, Conselho Editorial).

[34] Riaudel, M. (2007) O palimpsesto: o Amazonas de Júlio Verne, das fontes à ficção, in Revista da USP, pp. 66-74.

[35] Senna, E. (2006) O Velho Comércio do Rio de Janeiro. 2nd ed. (Rio de Janeiro: G.Ermakoff).

[36] Tocantins, L. (2009) Formação Histórica do Acre, I and II. (Brasília: Edições do Senado Federal).

[37] Vasquez, P. K. (2000). Fotógrafos alemães no Brasil do século XIX. (São Paulo: Metalivros).

[38] Vergara, M. R. (2011) The Popularization of Science and the Idea of Territory in the Brazilian First Republic: the José Veríssimo Phase of the Revista Brasileira (1895-1900), in Almagest: International Journal for the History of Scientific Ideas, II, pp. 101-113.

[39] Vergara, M. R. (2011) Ciências, fronteiras e nação: comissões mistas de demarcação dos limites territoriais entre Brasil e Bolívia, 1895-1901, in Boletim do Museu Paraense Emílio Goeldi.Ciências Humanas, 5(2), pp. 345-361. 